\title{
Genentech discloses safety concerns over Avastin
}

On August 13, Genentech and the US Food and Drug Administration (FDA) disclosed that a notice had been sent to physicians relating to Genentech's antibody drug, Avastin. This episode gives a warning to other companies that similar drugs targeting the endothelium may raise safety concerns when used in combination therapy.

The drug, the first targeted angiogenesis inhibitor to reach the market, binds vascular endothelial growth factor (VEGF) and therefore prevents the formation of new blood vessels. It was approved in the US in February 2004 for the treatment of colon cancer in combination with a chemotherapy regimen that includes 5 -fluorouracil (5-FU) (Nat. Biotechnol. 22, 371-374, 2004). Five months after that approval, Genentech issued a 'Dear Doctor' letter, dated July 2004 which states that the company had discovered a twofold increase in serious arterial thromboembolic events in some colon cancer patients who received Avastin in conjunction with 5-FU compared to standard chemotherapy care. Genentech, in S. San Francisco, California, now estimates the overall risk of such events in all Avastintreated patients at up to $5 \%$.

As it seeks to broaden indications for Avastin, including its use as front-line therapy in colorectal cancer and potentially in other types of cancer, Genentech's task is to further tease out whether the drug's possible contribution to inflammation, leading to embolic disease, is limited to colon cancer patients receiving 5-FU-based therapy Compounding the concern is Genentech's experience with Avastin in non-small cell lung cancer, which resulted in serious and in some cases fatal hemoptysis-spitting up blood, which may come from pulmonary embolism or from bleeding in the gastrointestinal tract, and so may be linked to endothelial damage.

Although oncologists were already aware of a heightened risk of thromboembolic events in some cancer patients, that risk may be more pronounced in the population of patients treated with Avastin. A meta-analysis of five completed colon cancer trials uncovered the increase in adverse events in patients who received Avastin in conjunction with infusional 5-FU-based chemotherapy. (The combination of 5-FU and leucovorin, plus another chemotherapeutic, irinotecan, is the current standard of care for treating metastatic colon cancer.) The adverse thromboembolic events include

\begin{tabular}{|c|c|c|c|c|c|}
\hline Company & Drug & Type & Target & Indication & Stage \\
\hline $\begin{array}{l}\text { Genentech } \\
\text { (South San Francisco, } \\
\text { CA, USA) }\end{array}$ & Avastin & $\begin{array}{l}\text { Monoclonal } \\
\text { antibody }\end{array}$ & VEGF & $\begin{array}{l}\text { Colorectal } \\
\text { cancer }\end{array}$ & Approved \\
\hline $\begin{array}{l}\text { Regeneron } \\
\text { (Tarrytown, NJ)/ } \\
\text { Aventis } \\
\text { (Bridgewater, NJ, USA) }\end{array}$ & VEGF trap & $\begin{array}{l}\text { Decoy } \\
\text { receptor }\end{array}$ & VEGF & $\begin{array}{l}\text { Non-Hodgkins } \\
\text { lymphoma }\end{array}$ & Phase 1 \\
\hline $\begin{array}{l}\text { Novartis (Basel)/Schering } \\
\text { (Berlin) }\end{array}$ & $\begin{array}{l}\text { PTK787/ZK } \\
222584\end{array}$ & $\begin{array}{l}\text { Small } \\
\text { molecule }\end{array}$ & VEGFR & $\begin{array}{l}\text { Metastatic } \\
\text { cancer }\end{array}$ & Phase 3 \\
\hline Pfizer (New York) & SU11248 & $\begin{array}{l}\text { Small } \\
\text { molecule }\end{array}$ & VEGFR & $\begin{array}{l}\text { Colon } \\
\text { cancer }\end{array}$ & Phase 3 \\
\hline $\begin{array}{l}\text { Aeterna } \\
\text { (Quebec City, Canada) }\end{array}$ & Neovastat & $\begin{array}{l}\text { Cartilage } \\
\text { extract }\end{array}$ & VEGFR & $\begin{array}{l}\text { NSC lung } \\
\text { cancer }\end{array}$ & Phase 3 \\
\hline
\end{tabular}

strokes, myocardial infarctions, transient ischemic attacks and angina.

Hal Barron, Genentech's senior vice president, development, and chief medical officer, cautions that any hypothesis as to the cause of these adverse events is at this point speculative. Colon cancer patients and adenocarcinoma patients in general are known to have increased risk of prothrombotic events. Moreover, "It isn't absolutely known if the effect seen with Avastin can be generalized beyond the population of metastatic colon cancer patients receiving 5 -FU," he points out.

"The implications of it being unique to 5 -FU or to colon cancer would be very important for clinicians to understand," says Barron. It is as likely, however, that the effect is related to the use in colon cancer treatment of chemotherapy in combination with other treatments. And given that developers of targeted therapies largely assume they will be used in combination with other treatment, it's probable that similar safety concerns will also appear during commercialization of other colon cancer therapies.

Indeed, this is something that other companies developing drugs targeting VEGF will have to consider. Physicians will have to be wary of all types of VEGF inhibitors, which include antibodies, the fusion protein VEGF trap (which combines portions of human VEGF receptor and VEGF) and inhibitors of VEGF receptor tyrosine kinase (see Table 1). The first VEGF-targeting drug, Pfizer's receptor tyrosine kinase inhibitor SU5416 (which Pfizer acquired when it bought Sugen), exhibited severe toxicities that included thromboem- bolic events, when it was used in combination with 5-FU/leucovorin in colon cancer patients, prompting Pfizer to discontinue development. Pfizer is now testing a successor compound, SU11248, which also targets VEGF.

Barron also points out that despite the fact that as much as $5 \%$ of all patients using Avastin may be at increased risk of a serious or fatal thromboembolic event, the increased risk does not change the basic risk/benefit ratio of using the drug. "When you think about side effects you're really thinking about competing risks," he says. "Despite the risk of thromboembolic events, our statistically rigorous analysis shows that in over-65-year old patients, an improvement in median survival was maintained. Clinicians' concerns are tempered by the fact that the net benefit is still in the patient's favor."

Overall, patients given Avastin survived about five months longer. But the survival advantage with Avastin is small, notes Samuel Waxman, an oncologist at Mt. Sinai Hospital School of Medicine in New York. And although that may not be a factor in a person with late-stage disease and only a few months to live, for others, he points out, including younger patients, "it's a real complication. We must also worry about using Avastin up-front, as first-line treatment. The issues are different when the goal is to prevent recurrence and a patient is exposed to combinations of drugs over longer periods of time." To be sure, as they plan late-stage trials, such concerns won't be lost on other developers of targeted cancer therapies.

Mark Ratner, Cambridge, Massachusetts 